\title{
LISTS OF HIEROGLYPHICAL SIGNS AND WORDS IN THE FUNERARY INSCRIPTION OF NETER-NEKHT
}

\author{
BY \\ A. Rowe \\ (Anthor of "Guide to Egyptian Antiquities in the \\ South Australian Museum”).
}

In Plate xxvii. of the present volume I gave a complete copy of the Egyptian text on the coffin of Neter-Nekht in the Australian Museum, and I now present full lists of the hieroglyphical signs and words in this ancient inscription.

With the aid of these lists and also the English rendering of the text printed in my former article ${ }^{1}$ it should be quite a simple matter for those interested to follow ont for themselves the Egyptian words.

For sake of clearness, the pictorial words and signs in the plates are all placed in the same direction, and the numbers of the lines refer to the numbers in my previously published plate.

The following transliteration of the Egyptian inscription on the coffin should also be found useful to the beginner:-

\section{TRANSLITERATION OF INSCRIPTION OF NETER-NEKHT.}

Line (1) amakhi kher Ast, maA-kherd. (2) amakhi kher Serqet, Neter-Nekht. (3) amakhi khfr paut neteru netchest, Neter-Nekht. (4) aMakhi kHer NebT-het, (5) AMAKHI KHER PAUT NETERU AAT, Neter-Nekht, maa [kherd]. (6) amakht kher Net, Neter-Nekht. nesut hetep da Anpe neb Sepa, khenti neter-het ; DA-F tCha-K Pet, sma-K ar en neter aA, neb pet, Neter-Nekht, ari en …...... Ti. (8) nesut hetep da Anpu, dep-du-f, am dt, neb Ta-'T'cheser, qerest nefeit em Semt-Amentet ; khep-f em hetep, Sep-sen, em as-F ent Neter-Kher, Neter[-Nekht]. amakhi kher Hapi, Neter.......... (10) amakhi kher Geb, Neter-Nekht. (11) amakhi er (doubtless kher) Not, Neter-Nekht. (12) amakhi kher Qebhennefo, Neter-Nekht. (13) nesut hetep da Asar neb Deddu, neter aA, Neb Abdu; da-F per-kherd ta, heqt, AH, apd, Menkh, Neter-senther, merhet, khet nebt nefert en mer ahet, Neter-Nekht. (14) amakhi kher Amsetha Neter-Nekht. (15) amakhi kher Shd, Neter-......... amakhi kher Tefnet, Neter-Nekht. (17) amakhi kher Duametef, NeTER-..........

'Rowe-" An Ancient Egyptian Coffin in the Australian Museum" (Recoids Australian Museum, xii., 8, 1919, p. 179.) 


\section{COFFIN OF NETER-NEKHT.}

Complete list of hieroglyphical signs.

Sign Value

Picture of

$$
\begin{gathered}
\text { Meaning (if an } \\
\text { ideograph) }
\end{gathered}
$$

Line No.

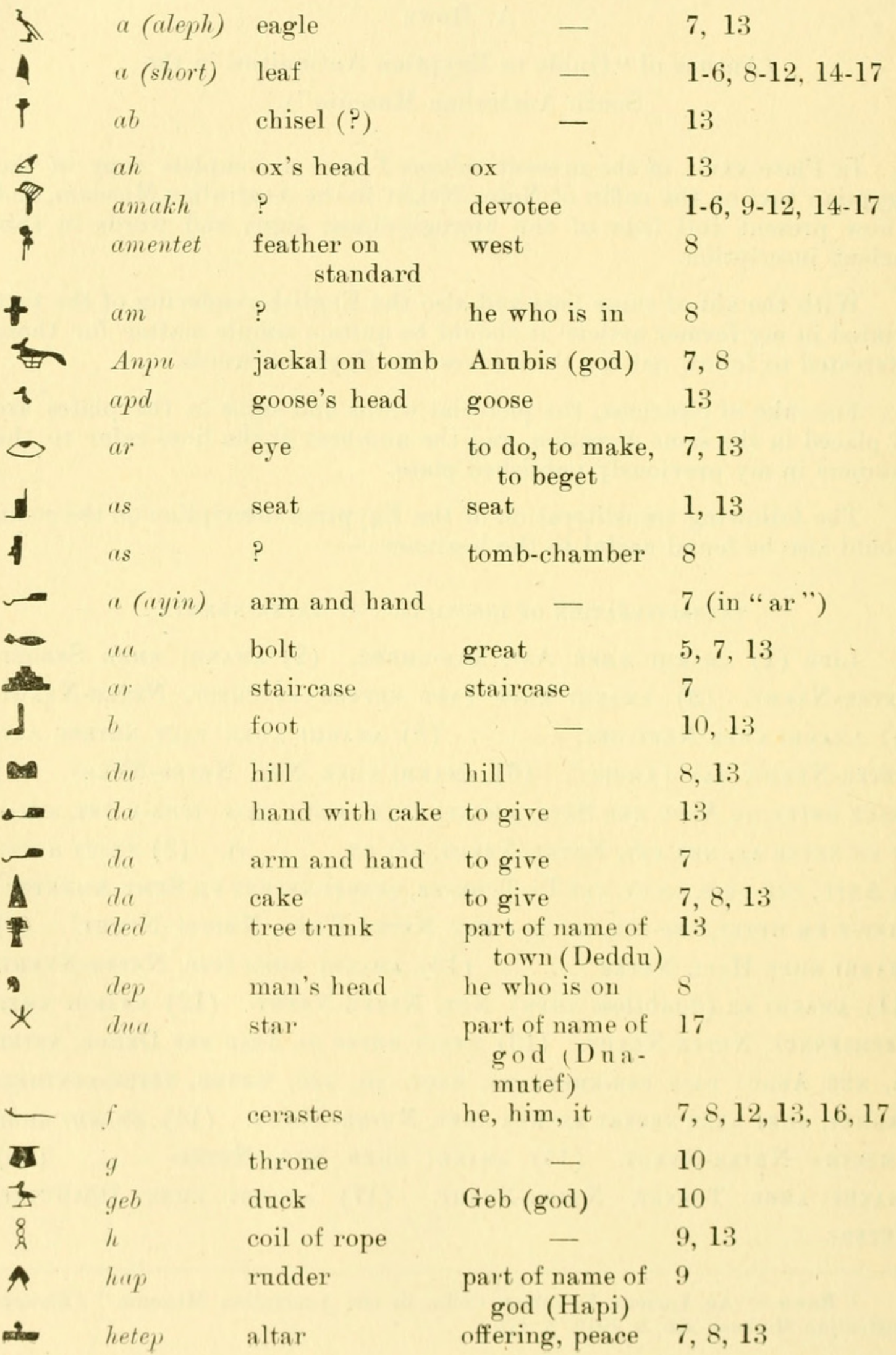


Sign

Value

Picture of

Meaning (if an ideograph)

Line No.

\begin{tabular}{|c|c|c|c|c|}
\hline$\delta$ & heqt & jug of ale & ale, beer & 13 \\
\hline & liet & shrine, or house & house, shrine & 7 \\
\hline 44 & $i$ & two leaves & - & $1-7,9-12,14-17$ \\
\hline & $k$ & bowl. & thee, thy & 7 \\
\hline 0 & lih & sieve & - & $1-17$ \\
\hline ॠ历 & klienti & 3 vases in stand & $\begin{array}{l}\text { governor, } \\
\text { dweller in }\end{array}$ & 7 \\
\hline,$- l[l]$ & kleeru & mace $(?)$ & word, voice & 1,13 \\
\hline & $m$ & owl & - & 8 \\
\hline$\sqsubset$ & $m$ & $?$ & - & 14 \\
\hline ـ & $\begin{array}{l}m a, \text { or } \\
m u(?)\end{array}$ & hand with cake & $\begin{array}{l}\text { part of name } \\
\text { of god (Dua- } \\
\text { mutef) }\end{array}$ & 17 \\
\hline$=$ & maa & reed & truth, right & 1,5 \\
\hline & $\begin{array}{l}\text { menlih } \\
\text { mer }\end{array}$ & $\begin{array}{l}\text { loom } \\
\text { tongue }\end{array}$ & $\begin{array}{l}\text { linen clothes } \\
\text { overseer }\end{array}$ & $\begin{array}{l}13 \\
13\end{array}$ \\
\hline$\lambda$ & mer & hoe & $\begin{array}{l}\text { part of word } \\
\text { for "oil",; also } \\
\text { to "love", }\end{array}$ & 13 \\
\hline & merliet & vessel of oil & oil & 13 \\
\hline men & $n$ & $\begin{array}{l}\text { wavy line of } \\
\text { water }\end{array}$ & of, in, to, etc. & $2,6-8,10-13,16$ \\
\hline - & neb & bowl & lord & $7,8,13$ \\
\hline 白 & Nebt-het & bowl on house & Nephthys (goddes & ss) 4 \\
\hline t & nefer & $\begin{array}{l}\text { heart \& lungs or } \\
\text { musical instrument }\end{array}$ & $\begin{array}{l}\text { beautiful, happy } \\
\text { it }\end{array}$ & 8,13 \\
\hline$\downarrow$ & nesut & reed & royal, king & $7,8,13$ \\
\hline $\max$ & Net & shuttle & Neith (goddess) & 6 \\
\hline 7 & neter & axe & god, divine & $2,3,5-17$ \\
\hline$\underbrace{3,}_{1}\} \cdot \vec{T}$ & {$[n e] l i l i t$} & branch of tree & strength & $\begin{array}{l}2,3,5-7,10,11 \\
13,14,16\end{array}$ \\
\hline & neter-liher & axe on throne & cemetery & 8 \\
\hline r & netches & sparrow & small & 3 \\
\hline 8 & $n u$ & pot & - & 11 \\
\hline$\sqrt{188}$ & Nut & $\begin{array}{l}3 \text { pots ; sign for } \\
\text { heaven; female } \\
\text { determinative " } t \text { ' }\end{array}$ & Nut (goddess) & 11 \\
\hline
\end{tabular}




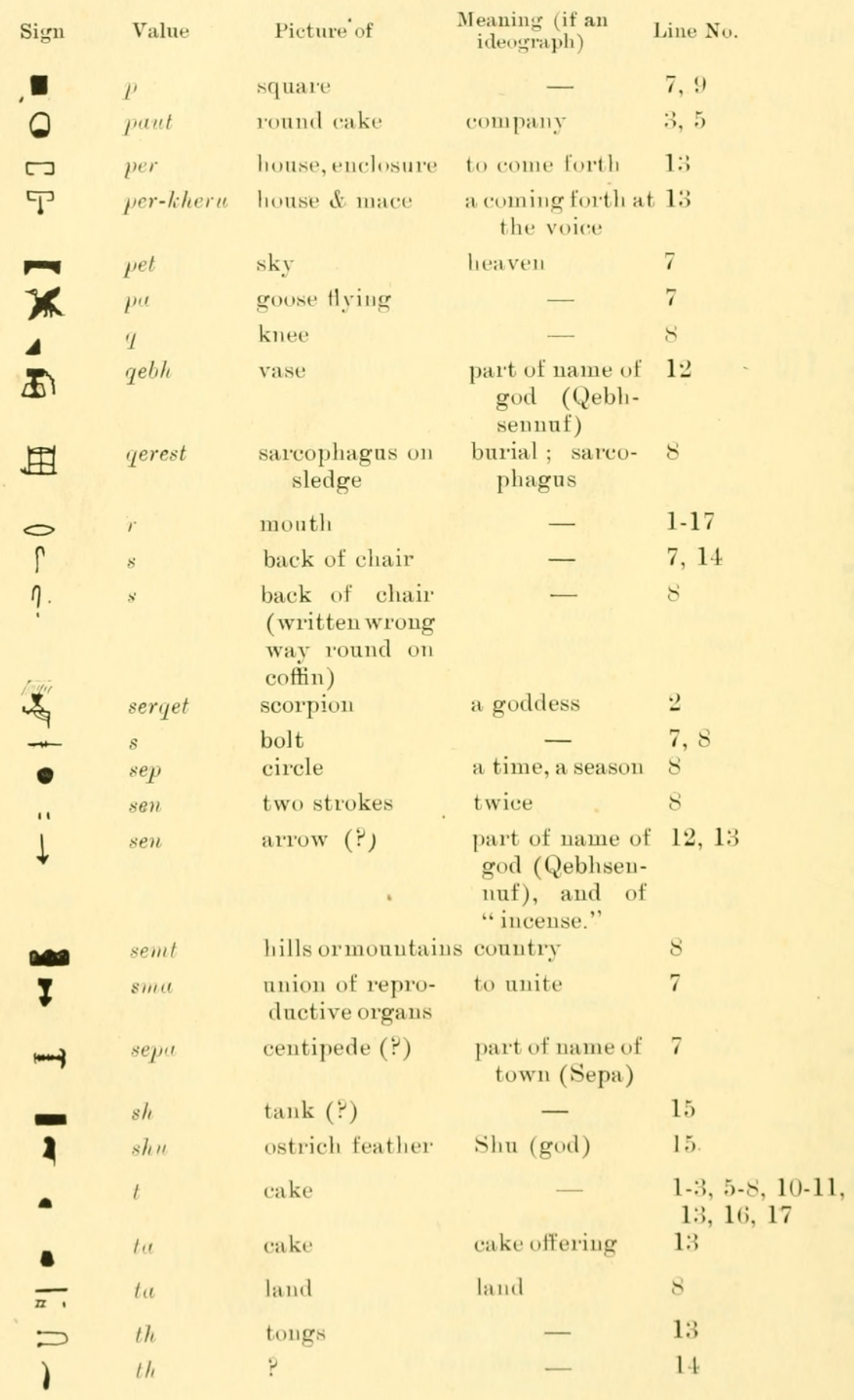


Sign Value Picture of $\begin{gathered}\text { Meaning (if an } \\ \text { ideograph) }\end{gathered}$ Line No.

$\begin{array}{lll}\text { teleser } & \text { hand with mace } & \text { holy, sacred } \\ \text { teluc } & \text { fire-stick (?) } & 7 \\ \text { chicken of the } & 8,13,15 \\ \text { quail } & \text { mummy bandages embalmment } & 8 \\ \text { ut } & \text { sacred eye of protection } & \text { (on eastern side } \\ \text { utchat } & \text { god Horus } & \text { of coftin) }\end{array}$

WORD DETERMINATIVES (not pronounced).

Sign Picture and Determinative of

$\otimes$

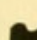

hills or mountains

E]

$\begin{array}{ll}\text { II } & \text { land } \\ \text { II } & \text { land } \\ \text { W1 } & \text { three strokes } \\ \text {... } & \text { three dots } \\ \text { 今 } & \text { pair of legs }\end{array}$

roll of papyrus tied up standard

$\operatorname{sky}$

ux boat
Remarks

Line

No.

has the value of " "nut," but

7,13 when written after names of towns is not pronounced

usual value of "semt," etc.; $\delta$ when used as a determinative, not pronounced

not to be confused with 8 "per" - to come forth

8

sign of plural 13

also sign of plural $\quad 12$

indicates action with legs, such as walking, running, etc.

sign of the abstract

names of gods and goddesses sometimes written on standards

although in most cases used as word for "heaven" it is also used as an unpronounced determinative, c.f., the word "Nut" (the sky-goddess) indicates a journey by 7 water 


\section{COFFIN OF NETER-NEKHT.}

Complete vocabulary of hieroglyphical words.

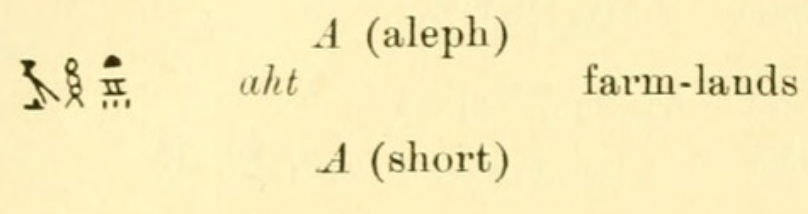

Line No. 13

Abydos (town)

13

oxen 13

Amsetha (god) 14

4) Amsethu

that am

40844 amakhi

$\$$ in amentet

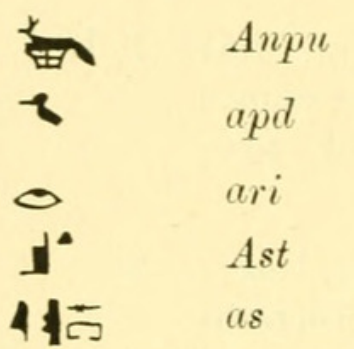

10 Asar

$$
A \text { (ayin) }
$$

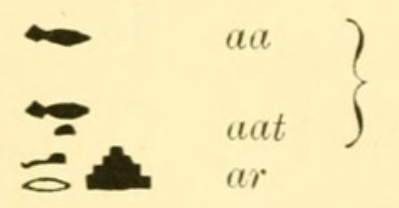

D

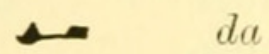

to give

13

to give

7

to give

Bnsiris

$7,8,13$

13: Deddu
*. Duamutef

Duamutef (god)

13

17

hill

be who is on

8

8
20 $\operatorname{dep} \operatorname{du-f}$ he who is on his hill 8
20 $\operatorname{dep} \operatorname{du-f}$ he who is on his hill 8

$$
F^{\prime}
$$

he, him, it, his

$7,8,13$ 


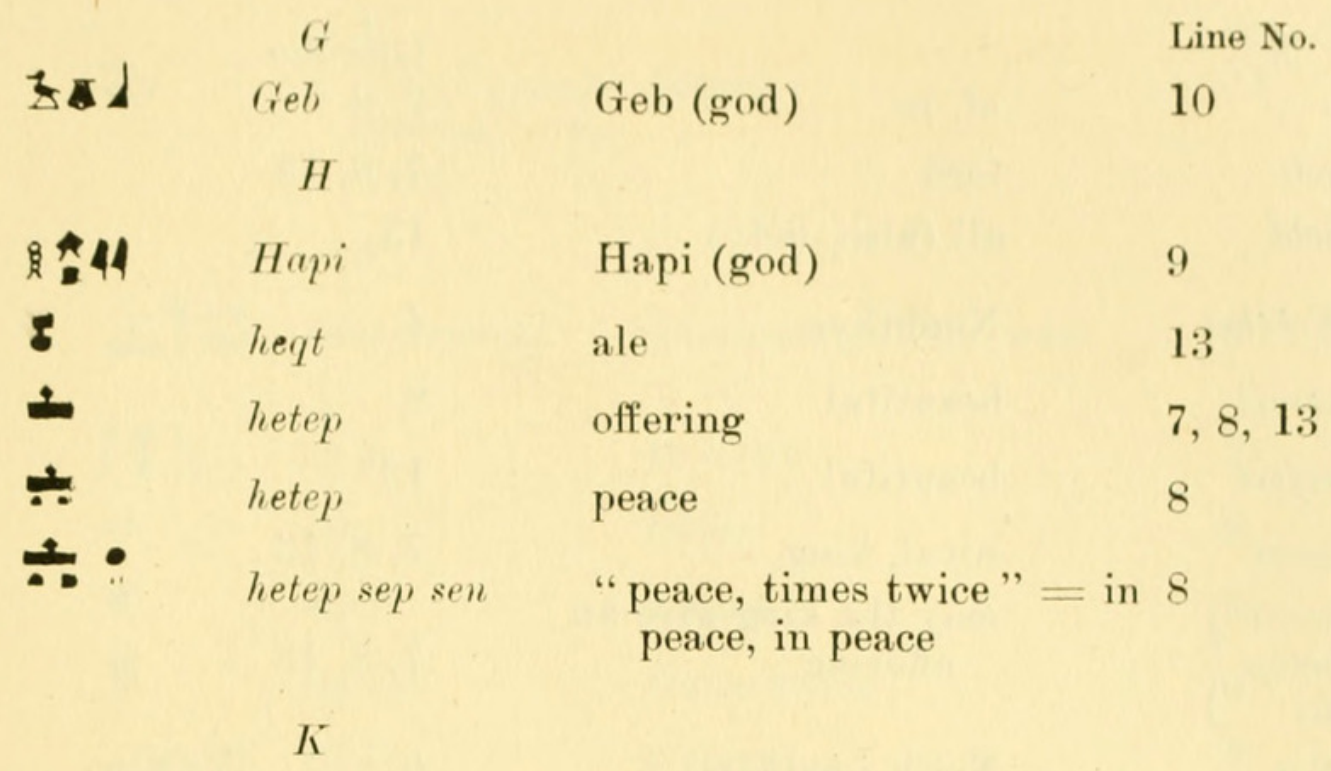

- ${ }_{\mathrm{KH}} \quad$ thee, thy

HWm lihenti

governor of, dweller in

7

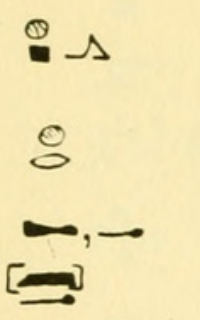

khep

to journey

8

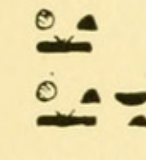

liker
kheru
(mua-kheru)
(

before

1-6,9,10,12,14-17

word

right of word

1,13

khet

things

1

liket nebt

"things all" = everything 13

\section{M}

$\begin{array}{ll}5 & \text { em } \\ \equiv & \text { maa } \\ \equiv & \text { mentih }\end{array}$

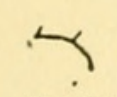

mer

in

right

right of word

1,5

linen garments

1

overseer

13

我密 mer ahet

overseer of farm lands

13

13

ธุo. merhet

oil

13 


\begin{tabular}{|c|c|c|c|}
\hline mans & $n^{N}$ & of, in & $\begin{array}{l}\text { Line No: } \\
7,8\end{array}$ \\
\hline & $n e b$ & lord & $7,8,13$ \\
\hline & $n e b t$ & all (also, lady) & 13 \\
\hline & Nebthet & Nephthys & 4 \\
\hline+2 & nefert & beautiful & 8 \\
\hline & nefert & beautiful & 13 \\
\hline & nesut & royal, king & $7,8,13$ \\
\hline & $\left.\begin{array}{l}\text { nesut } \\
\text { hetep } \\
d a\end{array}\right\}$ & $\begin{array}{l}\text { may the king give an } \\
\text { offering }\end{array}$ & $7,8,13$ \\
\hline$\sqrt{4}$ & Net & Neith (goddess) & 6 \\
\hline $9 \stackrel{2 m}{0}$ & Neter-Neliht) & & 6 \\
\hline & Neter-Neliht & name of the deceased & 5 \\
\hline 9 זum & Neter-Neliht & & 16 \\
\hline & neter. & god, divine & $7,8,13$ \\
\hline & neteru & gods & 3,5 \\
\hline 7 & neter-het & divine house & 7 \\
\hline & neter-kiher & cemetery & 8 \\
\hline $7+\sum_{1.1}^{\operatorname{man}}$ & neter-senther & incense & 13 \\
\hline 5 & netchest & little & 3 \\
\hline$\frac{\pi 8}{28}$ & $\begin{array}{l}\text { Nut } \\
\qquad P\end{array}$ & sky-goddess & 11 \\
\hline 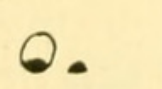 & pant & company & 3,5 \\
\hline p & per-liheru & a coming forth at the voice & 13 \\
\hline$\sqrt{18}$ & per-likern ta heqt & $\begin{array}{l}\text { cake and ale offerings which } \\
\text { come forth at the voice }\end{array}$ & 13 \\
\hline 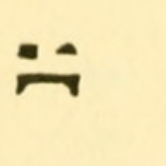 & pet & heaven & 7 \\
\hline Dt? & Qebhsenmui & a god & 12 \\
\hline $1 \eta \cdot 1$ & qerest & burial ; coffin & 8 \\
\hline
\end{tabular}


$R$

$\checkmark \quad$ er $($ or, $r)$ (an ab- before breviation for kher).

S
Line No.

11

mountains of the west

8

to unite 7

twice 8

a time 8

times twice 8

$\begin{array}{ll}\text { a town } & 7\end{array}$

a goddess 2

SH

$13 \quad s h u$

a god

15

$T$

$\begin{array}{lll}\text { ta } & \text { cake } & 13 \\ \text { ta } & \text { land } & 8 \\ \text { Ta-Tcheser } & \text { "Holy Land" } & 8\end{array}$

$14 \quad \ldots t i$

latter portion of name of deceased's parent (perhaps KHATI)

$T C H($ or, $D J)$

$12 \operatorname{los} t \operatorname{cha}$

to traverse, to sail

7 ,

the tcheser

see "Ta-Tcheser." The 8

latter word means

"holy."

U

2. ut

mummy chamber 



\section{$2 \mathrm{BHL}$ Biodiversity Heritage Library}

Rowe, A. 1919. "Lists of hieroglyphical signs and words in the funerary inscription of Neter-Nekht." Records of the Australian Museum 12, 293-302. https://doi.org/10.3853/j.0067-1975.12.1919.887.

View This Item Online: https://www.biodiversitylibrary.org/item/36172

DOI: https://doi.org/10.3853/j.0067-1975.12.1919.887

Permalink: https://www.biodiversitylibrary.org/partpdf/7633

\section{Holding Institution}

MBLWHOI Library

\section{Sponsored by}

MBLWHOI Library

\section{Copyright \& Reuse}

Copyright Status: NOT_IN_COPYRIGHT

This document was created from content at the Biodiversity Heritage Library, the world's largest open access digital library for biodiversity literature and archives. Visit BHL at https://www.biodiversitylibrary.org. 